\title{
COMMENTARY
}

\section{Time to dismantle systemic anti-Black racism in medicine in Canada}

\author{
OmiSoore Dryden PhD, Onye Nnorom MD MPH
}

Cite as: CMAJ 2021 January 11;193:E55-7. doi: 10.1503/cmaj.201579

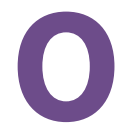

n May 25, 2020, George Floyd, an unarmed Black man, was murdered in the United States by White police officer Derek Chauvin who, in the course of arresting Mr. Floyd for allegedly using a counterfeit 20-dollar bill, knelt on his neck for almost 9 minutes. Mr. Floyd repeatedly said, "I can't breathe" (www.nytimes.com/2020/05/31/us/george -floyd-investigation.html). The video of this event, released on social media the next day, started a new chapter in history, sparking protests worldwide that demanded justice and an end to antiBlack racism. In response, the Toronto Board of Health declared anti-Black racism a public health crisis (www.cbc.ca/news/canada/ toronto/board-of-health-anti-black-racism-1.5603383), and several public health units in Ontario followed suit, acknowledging that race-based health inequities disproportionately affect Black and racialized communities. We consider the health impacts of anti-Black racism and discuss what the field of medicine must do to dismantle systemic racism in its structures and institutions.

Black people comprise 3.5\% of Canada's total population and about $43 \%$ of Black people in Canada are Canadian born. ${ }^{1}$ In Nova Scotia, there are large, centuries-old communities, including descendants of people who were enslaved in Canada. Although slavery was abolished in what was to become Canada in 1831, it was a foundational institution in the building of the nation. ${ }^{2,3}$ Black Canadians also represent diverse immigrant communities.

Systemic racism (also referred to as structural or institutionalized racism) refers to "the processes of racism that are embedded in laws (local, state, and federal), policies, and practices of society and its institutions that provide advantages to racial groups deemed as superior, while differentially oppressing, disadvantaging, or otherwise neglecting racial groups viewed as inferior." Anti-Black racism is a specific form of racism, rooted in the history and experience of enslavement, that is targeted against Black people, people of African descent. Myths and stereotypes were created and used to justify slavery and the torture of enslaved African people, including the idea that Black people were biologically different or subhuman, less intelligent, had a greater tolerance for pain and were not to be trusted, among many others. ${ }^{2}$

\section{KEY POINTS}

- Anti-Black racism is a specific form of racism, rooted in the history and experience of enslavement, that is targeted against Black people.

- Disparities between Black people and other groups with respect to medical conditions and risk factors are not explained by biological differences between "races."

- The field of medicine can no longer deny or overlook the existence of systemic anti-Black racism in Canada and how it affects the health of Black people and communities.

- We can address, confront and interrupt anti-Black racism in medicine by taking direction from leading experts both within and outside our profession. An easy step is to pay attention to the conversations Black people are having in our communities, including patients and health care professionals.

Although many Canadians may believe that racism is an issue only south of the border, Black Canadians have been raising awareness about anti-Black racism for centuries. In 2017, the United Nations expressed its deep concern at "the structural racism that lies at the core of many Canadian institutions and the systemic anti-Black racism that continues to have a negative impact on the human rights situation of African Canadians." ${ }^{5}$ The United Nations Working Group of Experts on People of African Descent noted that "across the country, many people of African descent continue to live in poverty and poor health, have low educational attainment and are overrepresented in the criminal justice system" and that systemic anti-Black racism is an upstream factor contributing to these outcomes. ${ }^{5}$ A 2011 study showed that, on average, Black Canadians earn 75.6 cents for every dollar a white person earns, even after controlling for age, education and immigration status. ${ }^{6}$ An analysis of Canadian Census data from 1996 to 2006 showed that $13.4 \%$ of Black people with a graduate degree in Montreal were unemployed, a rate comparable with that of non-Black people who had not completed high school (12\%). ${ }^{7}$

The stress of racism drives multiple upstream societal factors that perpetuate racial inequities in health for nondominant racial groups around the world, including both mental 
health and physical health conditions such as cardiovascular disease. ${ }^{8}$ Coronavirus disease 2019 (COVID-19) has disproportionately affected Black and racialized communities in Canada (www.cbc.ca/news/health/black-covid-antibody-study-1.5737452), the US (www.nationalgeographic.com/history/2020/04/corona virus-disproportionately-impacts-african-americans/) and the United Kingdom (www.theguardian.com/world/2020/may/07/ black-people-four-times-more-likely-to-die-from-covid-19-ons -finds). We know that observed disparities with respect to medical conditions and risk factors are not explained by biological differences between Black people and other groups. Race is a social construct based on nationality, ethnicity and other markers of social difference, many of which reflect differential access for Black people to power and resources in society. Lower socioeconomic status, be it measured by income, education or occupational status, has long been associated with poorer health outcomes. Accumulating evidence shows that racism drives multiple upstream societal factors that perpetuate racial inequities in health for multiple nondominant racial groups around the world. ${ }^{9}$ Structural inequalities disproportionately affecting racialized communities have contributed to their increased risk of both acquiring severe acute respiratory syndrome coronavirus 2 (SARS-CoV-2) and of having poorer outcomes. Poverty is racialized, as shown in a May 2020 ICES report on patterns of testing in Ontario that concluded that racialized people living in marginalized neighbourhoods have greater chances of testing positive for COVID-19. ${ }^{10}$

Reports of experiences of anti-Black racism in the Canadian health care system abound, particularly in the form of stereotyping and provider bias. ${ }^{9,11}$ This is compounded by the fact that a low proportion of physicians in Canada are Black. For example, in Ontario, Black people comprise $2.3 \%$ of practising physicians, yet $4.5 \%$ of Ontarians are Black. ${ }^{12}$ Systemic factors, including anti-Black racism, underpin the underrepresentation of Black people in medicine. ${ }^{13}$ Black physicians, physician trainees and racialized health care providers also report experiencing racism in Canadian health care institutions (www.cbc.ca/news/health/racism-canadian-medicine -doctors-1.5615554). ${ }^{14-16}$

In order to address the harmful health effects of anti-Black racism in Canada, we need to dismantle it. First, we who work in health care must acknowledge the existence of anti-Black racism in our systems and commit to meaningful, sustained change. We can do this by listening to the voices of Black Canadians, patients and health care professionals who have been grappling with anti-Black racism for generations, and by engaging with the many communities that have made recommendations for meaningful change to address the problem. For instance, the United Nations' Working Group of Experts on People of African Descent details how anti-Black racism affects the social determinants of health of Black Canadians and provides broad recommendations that include focusing on culturally appropriate and accessible mental health and HIV resources, partnering with Black communities and collecting disaggregated race-based data across all Canadian institutions. ${ }^{5}$ The Black Experiences in Healthcare Report 2020 is an excellent resource for physicians across the country to edu- cate themselves regarding the experiences of Black Canadian patients. ${ }^{11}$ Recommendations for change include training health care providers in anti-racism, anti-oppression and decolonialization, as well as routinely collecting race-based data in partnership with racialized communities. Finally, the Black Medical Student Association of Canada provides recommendations for medical schools to address anti-Black racism in medical education and admissions, and outlines the need for medical reform to be guided by critical race theory. ${ }^{17}$ Their recommendations set out both short- and long-term goals, and provide specific direction in relation to curriculum and accountability, in an effort to make the medical school experience more reflective of Black communities and more responsive to Black medical students.

The field of medicine can no longer deny or overlook the existence of systemic anti-Black racism in Canada and how it affects the health of Black people and communities. It is time to acknowledge and commit to dismantling systemic racism within our institutions of care and education. There are sufficient Canadian data that show how anti-Black racism predisposes to poor health outcomes. The testimonies of multiple patients who have experienced racism in Canadian health care have been collected and recommendations from expert groups are available to guide us. What will history write about our profession's responses and actions?

\section{References}

1. Maheux H, Do D. Diversity of the Black population in Canada: an overview. Cat no 89-657-X2019002. Ottawa: Statistics Canada; 2019. Available: www150. statcan.gc.ca/n1/pub/89-657-x/89-657-x2019002-eng.htm (accessed 2020 Aug. 29).

2. Maynard R. Policing Black lives: state violence in Canada from slavery to the present. Black Point (NS): Fernwood Publishing; 2017.

3. Whitfield HA. North to bondage: loyalist slavery in the Maritimes. Vancouver: UBC Press; 2016.

4. Williams DR, Lawrence JA, Davis BA. Racism and health: evidence and needed research. Annu Rev Public Health 2019;40:105-25.

5. Report of the Working Group of Experts of African Descent on its mission to Canada. Agenda item 9: Racism, racial discrimination, xenophobia and related forms of intolerance, follow-up to and implementation of the Durban Declaration and Programme of Action. New York: United Nations General Assembly; 2017. Available: https://ansa.novascotia.ca/sites/default/files/files/report -of-the-working-group-of-experts-on-people-of-african-descent-on-its-mission -to-canada.pdf (accessed 2020 Aug. 24).

6. Block S, Galabuzi G-E. Canada's colour coded labour market: the gap for racialized workers. Ottawa: Canadian Centre for Policy Alternatives; 2011. Available: www.wellesleyinstitute.com/wp-content/uploads/2011/03/Colour_Coded_ Labour_MarketFINAL.pdf (accessed 2020 Nov. 26).

7. Community Economic Development and Employability Corporation (CEDEC). African-Canadian Career Excellence undergraduate survey 2011-2012: summary report. Huntingdon (QC): Community Economic Development and Employability Corporation; 2013. Available: https://cedec.ca/wp-content/ uploads/2015/02/CEDEC-ACCE-Final-Undergraduate-Report_June-26-2013_ ENG_Rebranded.pdf (accessed 2020 Sept. 20).

8. Levy J, Ansara D, Stover A. Racialization and health inequities in Toronto. Toronto: Toronto Public Health; 2013. Available: www.toronto.ca/legdocs/ mmis/2013/hl/bgrd/backgroundfile-62904.pdf (accessed 2020 Aug. 18).

9. Waldron IRG. The impact of inequality on health in Canada: A multi-dimensional framework. Diversity in Health and Care 2010;7:261-70.

10. Chung H, Fung K, Ferreira-Legere LE, et al. COVID-19 laboratory testing in Ontario: patterns of testing and characteristics of individuals tested, as of April 30, 2020. Toronto: ICES; 2020. Available: https://www.ices.on.ca/Publications/ Atlases-and-Reports/2020/COVID-19-Laboratory-Testing-in-Ontario (accessed 2020 Nov. 26) 
11. Black experiences in health care symposium: bringing together community and health systems for improved health outcomes. North York (ON): Black Health Alliance; Toronto: Health Commons Solutions Lab; Toronto: Sinai Health; 2020. Available: https://static1.squarespace.com/static/ 5a0d40298dd041f9a60bb3a7/t/5ea9a317983eca78fd95ee6d/1588175652047/ Full+Report-+Black+Experiences+in+Health+Care+Symposium+2020.pdf (accessed 2020 Sept. 20).

12. Kralj, Boriz. MedicalPost. Unrecognized physician pay inequities in Canadian medicine. 2019. Available: drbobbell.com/unrecognized-physician-pay -inequities-in-canadian-medicine/ (accessed 2020 Aug. 29).

13. Osei-Yeboh C. How Queen's School of Medicine barred Black students for 40 years. INKspire; 2020. Available: https://inkspire.org/post/how-queens-school-of -medicine-barred-black-students-for-40-years/-M2ix2zV7yw8Y-V--XUQ (accessed Aug. 29).

14. Mpalirwa J, Lofters A, Nnorom O, et al. Patients, pride, and prejudice: exploring Black Ontarian physicians' experiences of racism and discrimination. Acad Med 2020;95:S51-7.

15. Das Gupta T. Real nurses and others: racism in nursing. Black Point (NS): Fernwood Publishing; 2009. Available: https://fernwoodpublishing.ca/book/ real-nurses-and-others (accessed 2020 Aug. 29).

16. Vazir S, Newman K, Kispal L, et al. Perspectives of racialized physiotherapists in Canada on their experiences with racism in the physiotherapy profession. Physiother Can 2019;71:335-45.

17. Recommendations to Canadian faculties of medicine. Black Medical Students' Association of Canada (BMSAC). Available: https://drive.google.com/file/d/12Gdf4_ lejRWMiJAQ3PXwt_3pUqKRIWrx/view?fbclid=IwAR3hjd2WRQ-GqhObNjq-oNSBOz2P -_6E7p2z7-zsYpdB6rvs6VI80WibT9A (accessed 2020 Sept. 29).
Acknowledgement: The authors thank Dr. Mark Hanson and Dr. Saleem Razack for their assistance with this commentary.

Competing interests: None declared.

This article has been peer reviewed.

Affiliations: Department of Community Health and Epidemiology (Dryden), Dalhousie University, Halifax, NS; Dalla Lana School of Public Health (Nnorom), University of Toronto, Toronto, Ont. The authors are co-leads of the Black Health Curricular Collaborative.

Contributors: Both authors contributed to the conception and design of the work, drafted the manuscript, revised it critically for important intellectual content, gave final approval of the version to be published and agreed to be accountable for all aspects of the work.

Content licence: This is an Open Access article distributed in accordance with the terms of the Creative Commons Attribution (CC BYNC-ND 4.0) licence, which permits use, distribution and reproduction in any medium, provided that the original publication is properly cited, the use is noncommercial (i.e., research or educational use), and no modifications or adaptations are made. See: https://creativecommons.org/licenses/by-nc-nd/4.0/

Correspondence to: OmiSoore Dryden, omisoore.dryden@dal.ca 